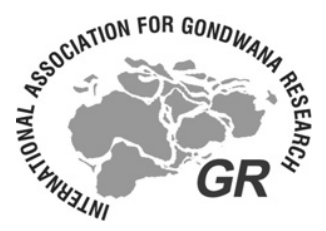

www.elsevier.com/locate/gr

\title{
Extensional tectonics and gravitational collapse in an Ordovician passive margin: The Western Argentine Precordillera
}

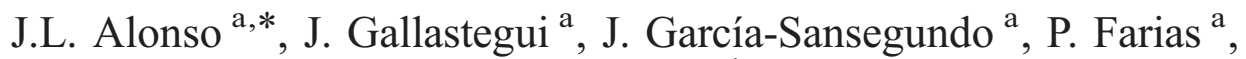 \\ L.R. Rodríguez Fernández ${ }^{\mathrm{b}}$, V.A. Ramos ${ }^{\mathrm{c}}$ \\ ${ }^{a}$ Department of Geology, University of Oviedo, c/ Arias de Velasco s/n, 33005 Oviedo, Spain \\ b Instituto Geológico y Minero de España, c/ La Calera, 1, 28740, Tres Cantos, Madrid, Spain \\ ${ }^{\mathrm{c}}$ Laboratorio de Tectónica Andina, Facultad de Ciencias Exactas y Naturales, Universidad de Buenos Aires 1428, Buenos Aires, Argentina
}

Received 29 September 2006; accepted 28 May 2007

Available online 7 June 2007

\begin{abstract}
The paper describes ubiquitous extensional structures developed in a passive margin of Ordovician age in the Argentine Precordillera. These extensional structures include normal faults and boudinaged sequences. In some places the boudinage reaches very high extension values, giving rise to block-in-matrix formations. Most of these extensional structures developed when sediments were not well lithified, as recorded by hydroplastic fractures, slump folds and pinch-and-swell structures. The presence of slump folds coeval with the extensional deformation, the variable extension directions obtained from the kinematic analysis and a weak cleavage recording layer-perpendicular shortening support the interpretation that gravitational collapse related to submarine sliding was the cause for extensional deformation. Well-consolidated rocks, located at the lower part of the stratigraphic sequence, also display scarce extensional faults. These extensional faults predate folding because they were breached by flexural-slip faults and, as a result of their passive rotation in fold limbs, these initial normal faults may now appear as reverse faults, particularly in steep and overturned limbs. The truncation of extensional faults by flexural-slip faults produces typical bed thickness changes across the extensional faults, giving rise to apparent synsedimentary faults. These normal faults can be attributed to the crustal extension that generated the passive continental margin or may represent deep parts of faults related to gravitational collapse.
\end{abstract}

(C) 2007 International Association for Gondwana Research. Published by Elsevier B.V. All rights reserved.

Keywords: Submarine sliding; Extensional tectonics; Gondwana; Ordovician; Argentine Precordillera

\section{Introduction}

\subsection{General overview}

The Argentine Precordillera is a fold-and-thrust belt, about $80 \mathrm{~km}$ wide, which involves Palaeozoic and Tertiary sediments (Bracaccini, 1946; Heim, 1952). It is considered as a rifteddrifted microcontinent, originally located in Laurentia and accreted to the Gondwana margin. Reviews of the arguments for this proposition can be found in Benedetto (2004), Ramos (2004) and Rapalini and Cingolani (2004).

\footnotetext{
* Corresponding author.

E-mail address: jlalonso@geol.uniovi.es (J.L. Alonso).
}

The Precordillera has classically been divided into Western, Central and Eastern domains based on stratigraphic and structural features (Fig. 1). Regarding Early Palaeozoic palaeogeography, a carbonate platform of Cambrian to Middle Ordovician age extended over the Central and Eastern Precordillera, changing westwards from proximal to distal facies (Bordonaro, 1980; Baldis et al., 1982), while slope and oceanic facies occurred in the western Precordillera. The presence of Early Palaeozoic platform sediments in the east changing to slope facies westwards (Borrello, 1969a,b; Ramos et al., 1984; Cingolani et al., 1989; Spalletti et al., 1989) allows the identification of the ancient continental margin in the western part of the Precordillera (Astini, 1997; Keller, 1999). Ocean floor sediments and pillow basalts with mafic sills were recorded by the pioneer work of Borrello (1969a,b) in the westernmost part 


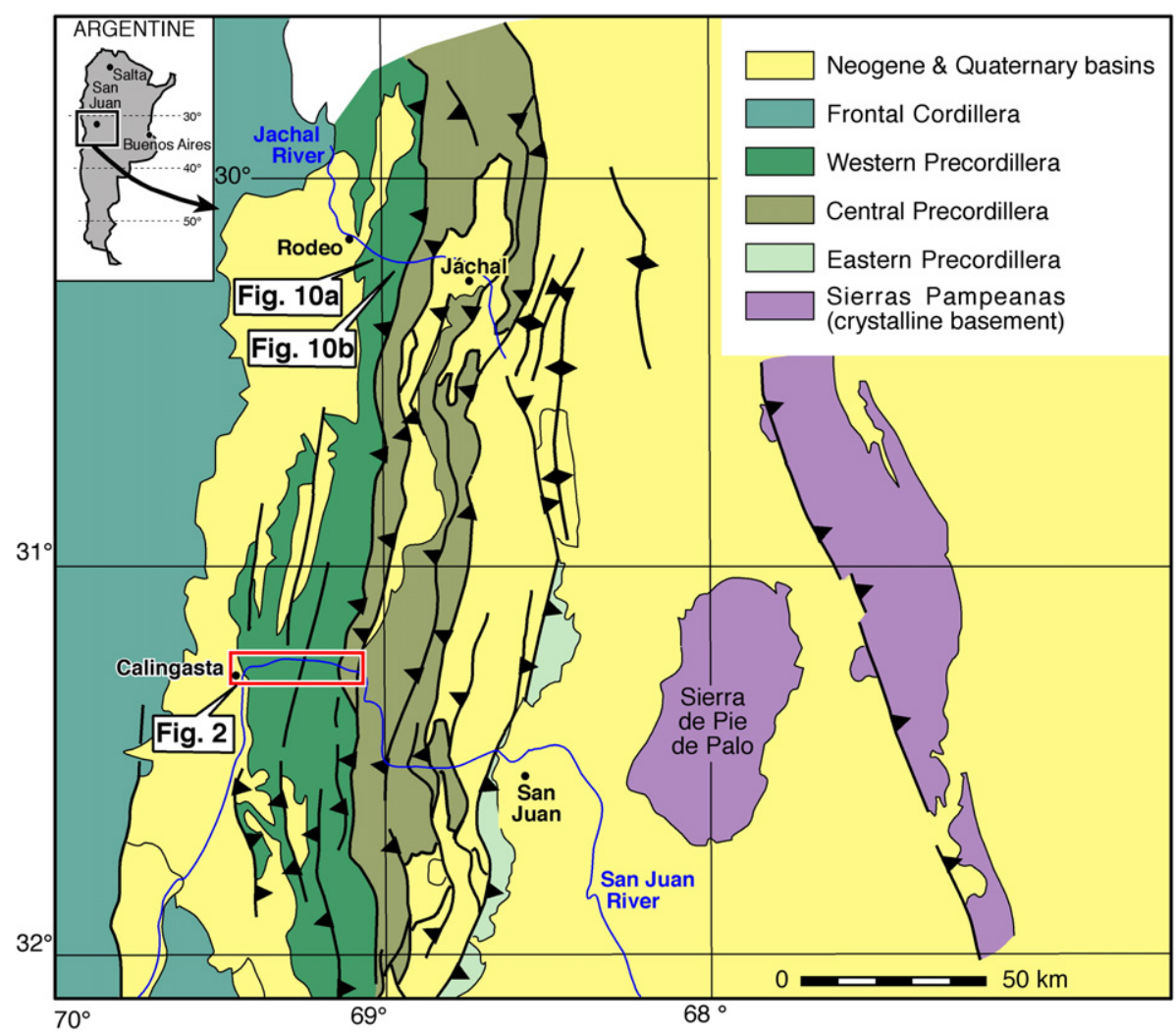

Fig. 1. Location and geological domains of the Argentine Precordillera showing the location of Figs. 2 and 10a and b.

of the Precordillera. Isotopic and geochemical data are consistent with an abnormal fast spreading oceanic ridge (E-MORB of Haller and Ramos, 1984; Kay et al., 1984). The slope deposits include block-in-matrix formations with blocks derived from the eastern carbonate platform. These mélange deposits have been usually interpreted as olistostromal formations (Borrello, 1969a,b).

This Early Palaeozoic continental margin remained stable until the Late Devonian times. Early Carboniferous deposits known as the El Ratón Formation (Azcuy et al., 1981) overlie folded and cleaved rocks of Devonian age with a strong angular unconformity. This deformation has been interpreted as the result of the collision of the Chilenia terrain against the Precordillera continental margin (Ramos et al., 1984, 1986). Triassic and Tertiary rocks lie with angular unconformity on Palaeozoic rocks but are also involved in the thrusting and folding in the Western Precordillera. Whether the Andean (postTertiary) structures are new or represent the reactivation of older ones is not well understood yet.

This paper focuses on the description and discussion of the significance of the extensional structures that we have identified in the Ordovician formations in the western Precordillera. These structures are particularly ubiquitous in the continental platform-ocean transition in this area and most of them are related to submarine sliding. This has important implications in the interpretation of the mélanges located in the western Argentine Precordillera and can contribute to a better understanding of the processes that control the evolution of passive continental margins.

\subsection{Stratigraphy of the Western Precordillera}

Fig. 2 shows a geological map and a cross-section of the Western Precordillera and the westernmost sector of the Central Precordillera along the Río San Juan section. The explanation of Fig. 2 summarizes the stratigraphy of this area. The oldest formation in the Western Precordillera is the Don Polo Formation, initially considered Late Proterozoic and later interpreted as Ordovician in age (Baldis et al., 1982), but not well constrained chronostratigraphically (Turco Greco and Zardini, 1984). This formation is composed of greywackes and shales with turbiditic features (Nullo and Stephens, 1996).

The well-dated Ordovician deposits in the Western Precordillera have been classically divided into several stratigraphic units. The Alcaparrosa Formation, located in the westernmost area of the Rio San Juan River section, contains ocean floor deposits, mainly shales with basic volcanics, including pillow lavas. It is partly of Middle to Upper Ordovician age (Amos et al., 1971; Aparicio and Cuerda, 1976; Kerllenevich and Cuerda, 1986; Schauer et al., 1987). To the N of the Rio San Juan section, the Alcaparrosa Formation passes laterally into the Yerba Loca Formation (Astini, 1988), which consists of sandstones and shales with intercalated layers of mafic volcanics with abundant graptolites of Caradoc age (Blasco and Ramos, 1977), that was recently extended into the Ashgill (Brussa et al., 1999).

The Los Sombreros Formation, located in the easternmost sector of the Western Precordillera, has been referred to as an 

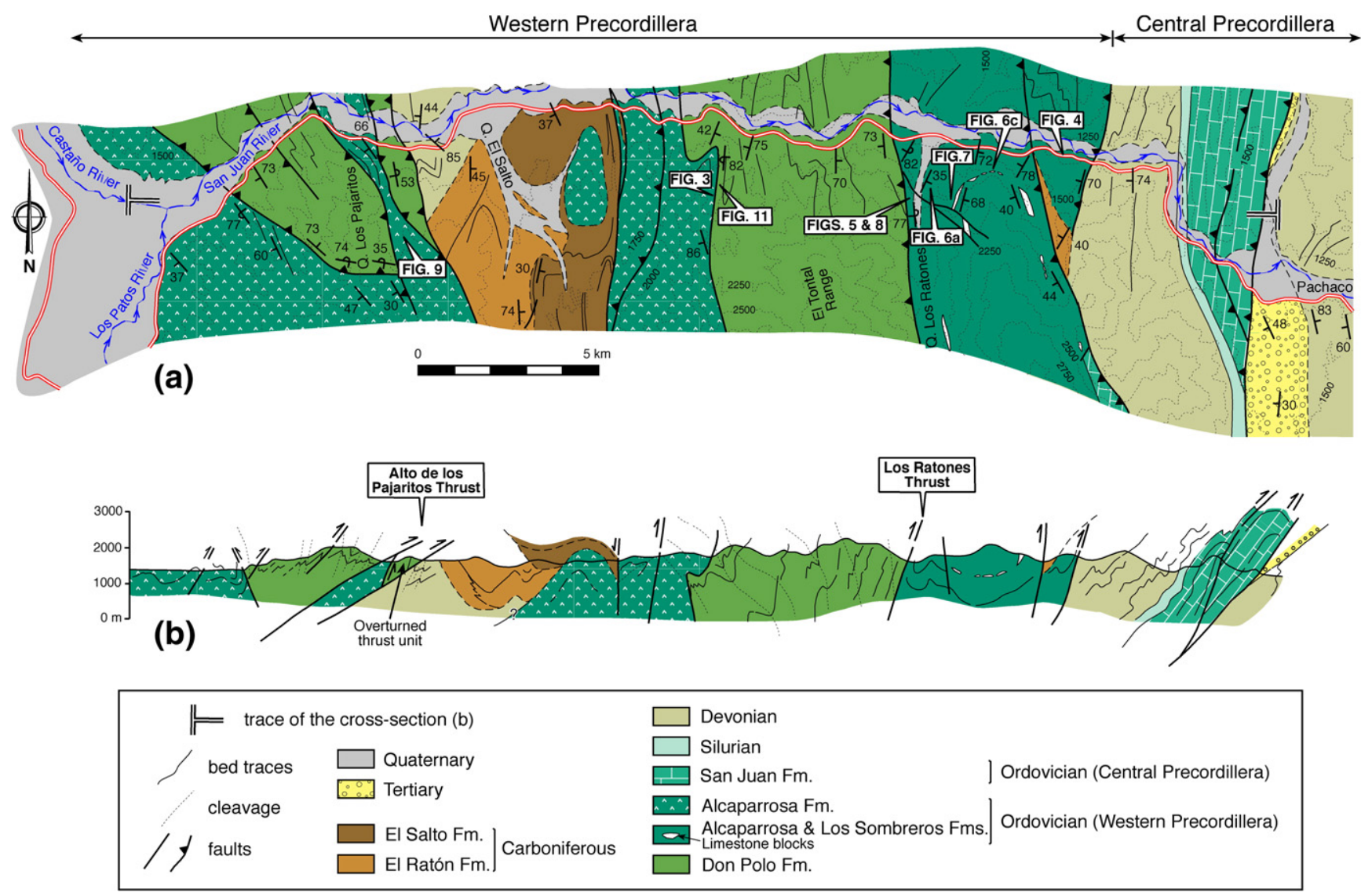

Fig. 2. (a) Geological map of the Western Precordillera and westernmost part of the Central Precordillera along the San Juan River. Location in Fig. 1. (b) Cross-section along the San Juan River. Its trace is shown in panel a.

olistostrome or mélange deposit derived from the CambrianOrdovician formations (Benedetto and Vaccari, 1992). This unit is a block-in-matrix formation containing up to hectometric size blocks of Middle Cambrian and Early Ordovician limestones, conglomerate levels with pebbles of gneisses and also mafic subvolcanic rocks. The shales of this formation have provided graptolite faunas of Upper Ordovician age. To sum up, the Los Sombreros Formation has been interpreted as the slope deposits and the Alcaparrosa Formation as the ocean floor deposits (Ortiz and Zambrano, 1981; Cuerda et al., 1985; Cingolani et al., 1989; Spalletti et al., 1989). Further south a sequence of greywackes and shales with turbiditic features and faunal content of Upper

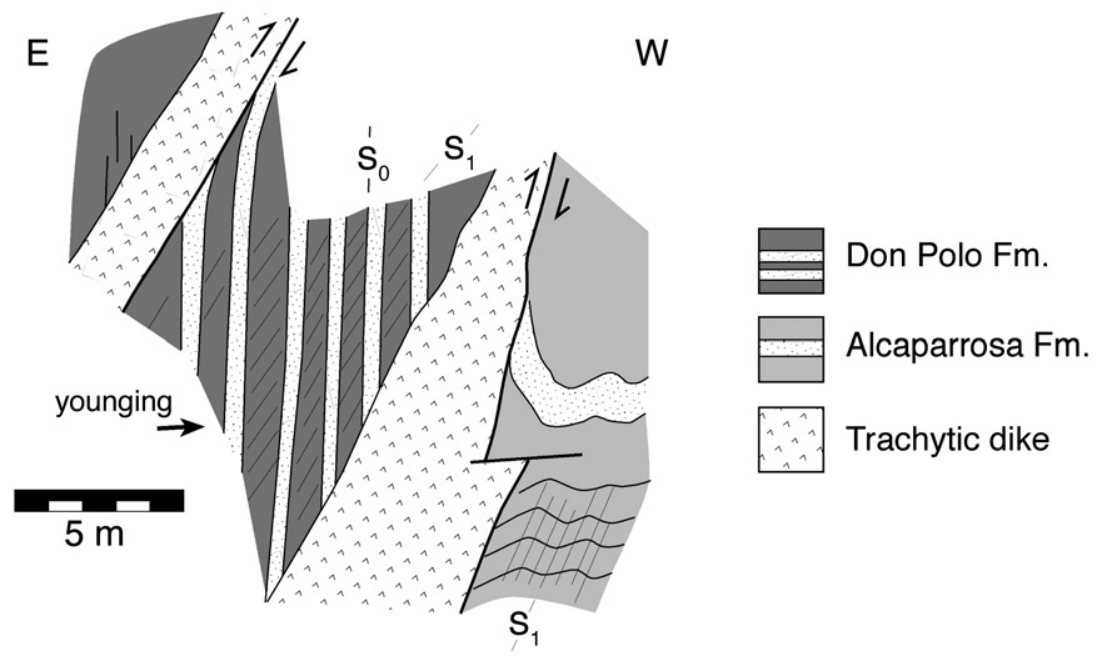

Fig. 3. Close up view of the structural relationship between the Don Polo and Alcaparrosa Formations at the western side of the Tontal Range. Location in Fig. 2a. 


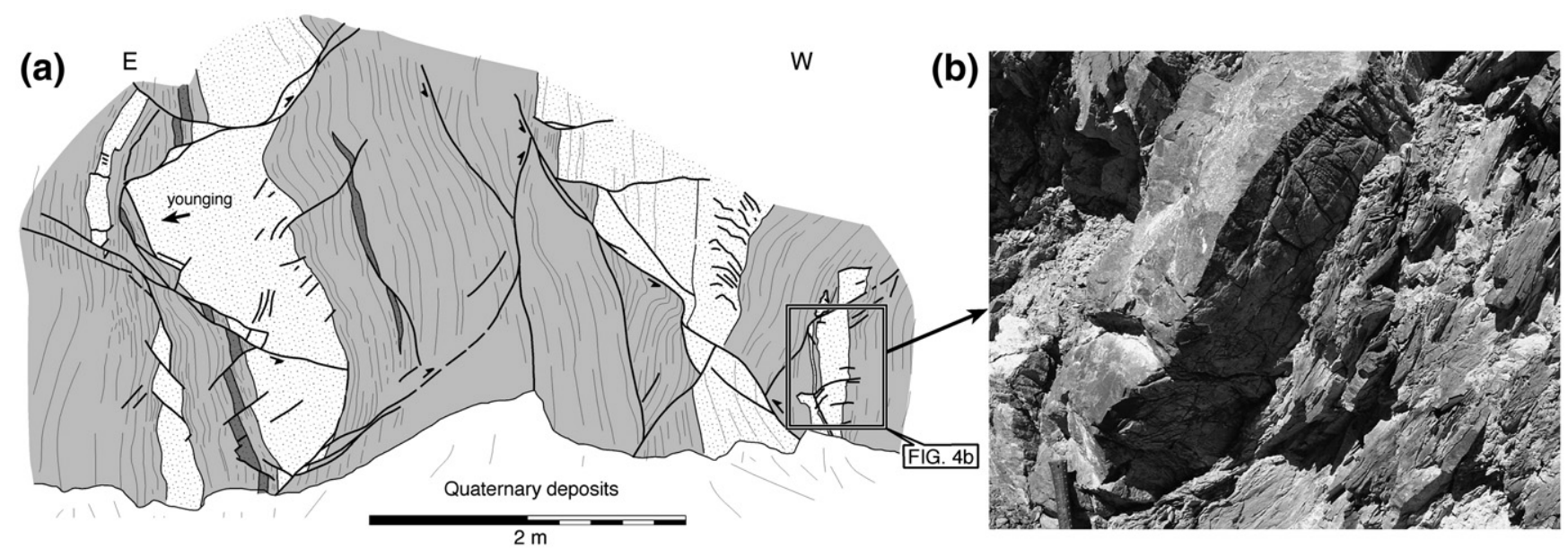

(c)
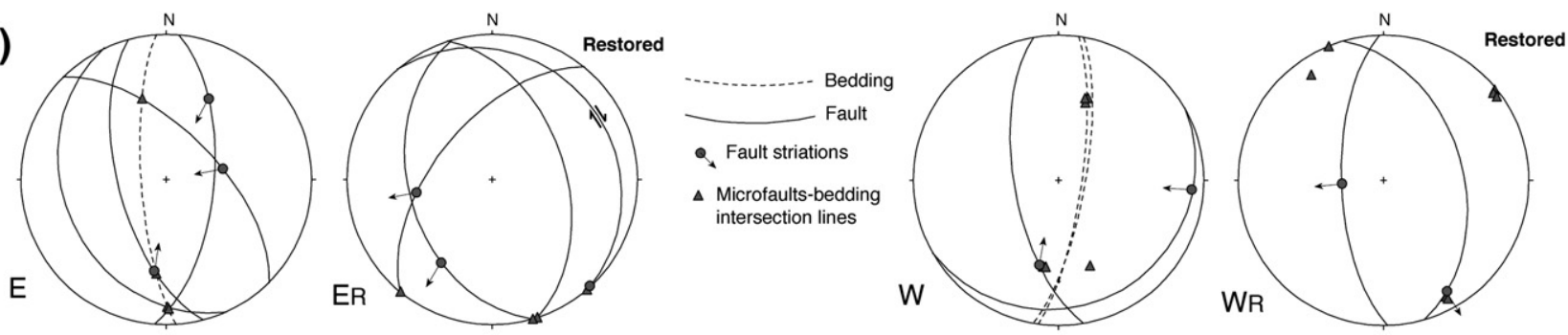

Fig. 4. (a) Outcrop sketch showing the geometry of extensional faults in a greywacke-shale sequence of the Alcaparrosa Formation. San Juan-Calingasta Road. Location in Fig. 2a. (b) Microfaults of hydroplastic type at the bottom of a sandstone bed. Location in panel a. (c) Stereoplots of structural elements of panel a. St: fault striations. E: eastern sector (overturned beds). W: Western sector (normal beds). Plots with subscript (R) in their labels show the attitude of the structural elements after restoration of the bedding to a horizontal attitude.

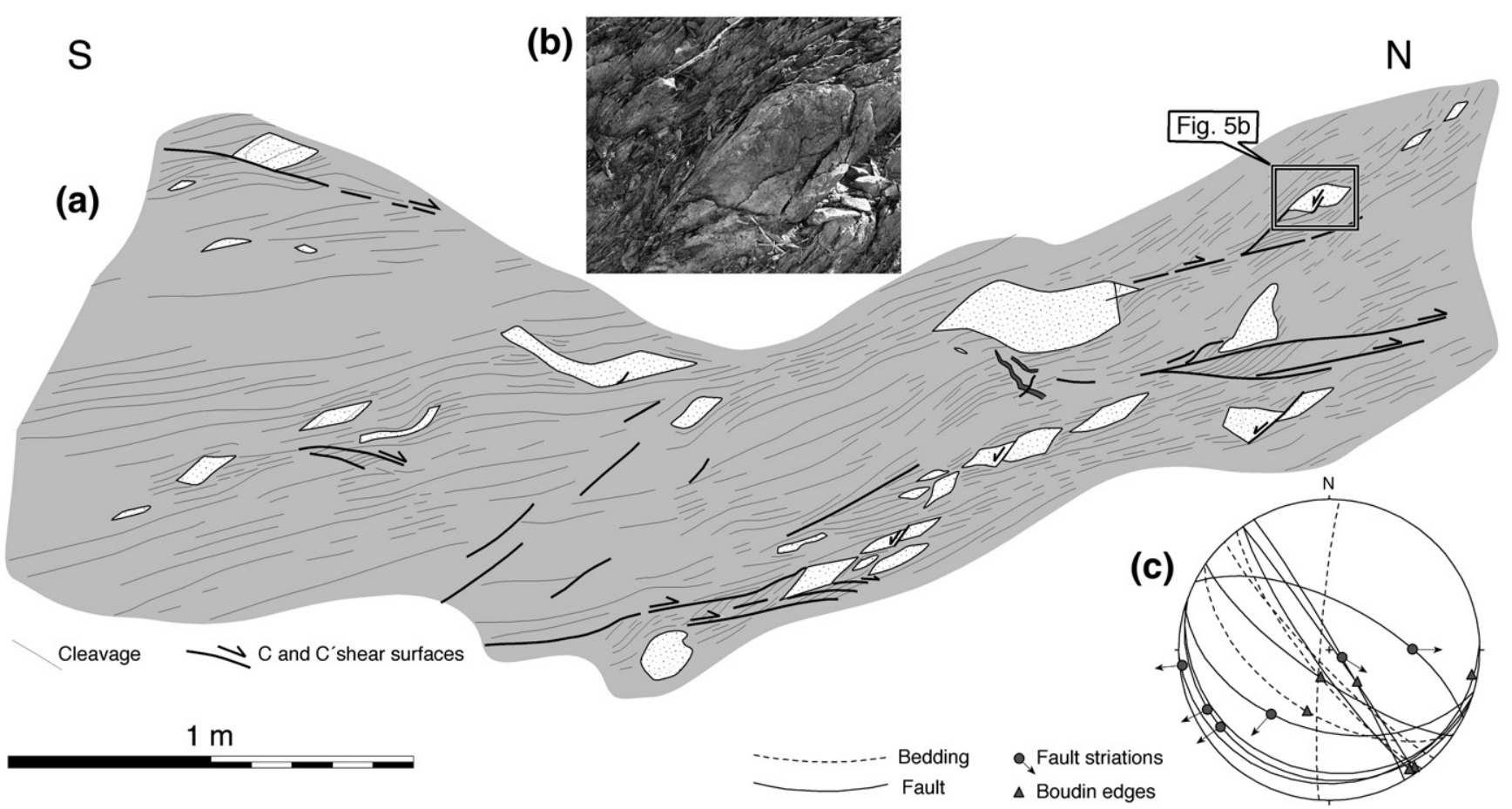

Fig. 5. (a) Outcrop sketch showing greywacke blocks included in a shale matrix. The Los Sombreros Formation. Location in Fig. 2a. (b) Rhombohedral block bounded by faults displaying striations. Location in panel a. (c) Stereoplot of structural elements of panel a. Legend as in Fig. 4. 
Ordovician age, referred as the Portezuelo del Tontal Formation, has been found in the Tontal Range (Cingolani et al., 1989).

In the western part of the Río San Juan section, a sandstoneshale sequence underlying unconformable Lower Carboniferous conglomerates of the El Ratón Formation (Azcuy et al., 1981; Amenabar and Di Pasquo, 2006) has been interpreted to be Devonian in age (Fig. 2a and b) and called the El Codo Formation (Sessarego, 1988). The El Salto Formation, of Upper Carboniferous-Lower Permian age (Heim, 1952; Manceñido and Sabatini, 1974; Manceñido et al., 1976a,b; Amos, 1981) rests unconformably above the El Ratón Formation.
In the Central Precordillera, the Early Palaeozoic is represented by the Cambrian-Ordovician platform limestones of the La Silla and San Juan formations (Fig. 2) (Keller, 1999; Astini, 2003). These limestones are overlain by Silurian shales and Devonian sandstones and shales (Heim, 1952). This Palaeozoic succession displays a stratigraphic gap of Upper Ordovician age (Bracaccini, 1949), interpreted as the evidence of a peripheral bulge produced during the inception of a foreland basin as a result of the collision of the Cuyania terrane against the Gondwana margin (Astini et al., 1996; Astini, 2003; Ramos, 2004).
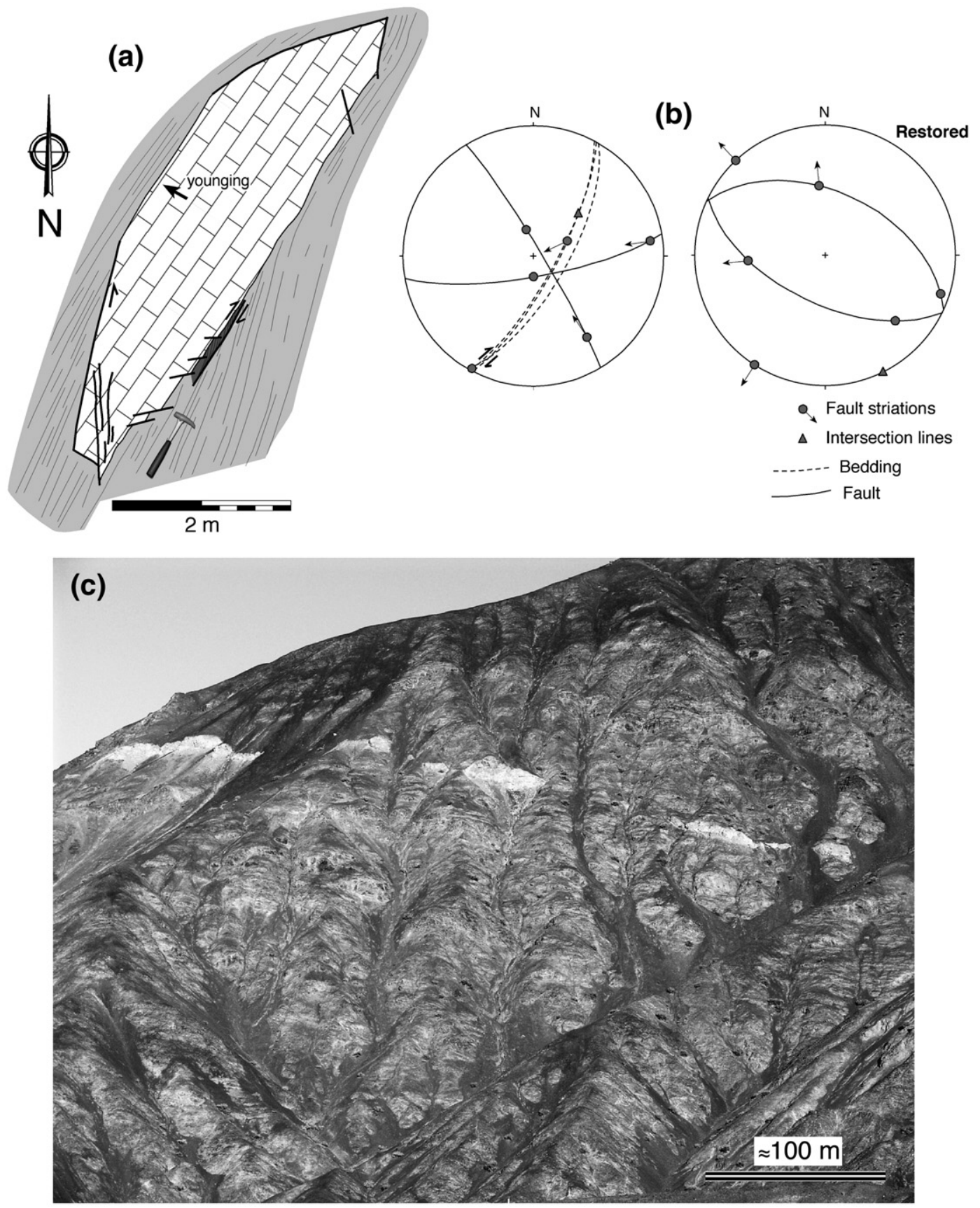

Fig. 6. (a) Limestone block included in a shale matrix. (b) Stereoplots of structural elements of panel a. Legend as in Figs. 4 and 5. (c) Photograph of limestone blocks lined up. Locations of a and $\mathrm{c}$ in Fig. 2a. 


\subsection{Structure of the Western Precordillera}

Our map and cross section of the Western Precordillera along the Rio San Juan section in Fig. 2 are very close to those produced by Von Gosen (1992). They differ in some structural details, particularly related to parts of the boundaries between the Don Polo and Alcaparrosa Formations, which are important for resolving disagreements over their stratigraphic order, as discussed below.

The main structures of the Western Precordillera along the Rio San Juan Section are east-verging thrust units that repeat an Ordovician to Devonian succession (Fig. 2b), although westverging thrusts also occur in the westernmost part of the section. The Carboniferous sequence rests unconformably on older rocks, truncating folds developed in the Devonian sequence to the west of the Quebrada del Salto. The existence of this preAndean deformation has been largely known in the Western Precordillera and related to a reactivation of the continental margin during Palaeozoic times (Ramos et al., 1984, 1986). The Carboniferous deposits also cover the thrust that constitutes the eastern boundary of the Western Precordillera to the east of the Quebrada Los Ratones (Fig. 2a and b). However, some of the thrust units also involve Carboniferous rocks (Fig. 2). This may be the result of the development of new thrusts during the Andean deformation or the rejuvenation of previous thrusts in Andean times.

Folds are also well developed at the Western Precordillera and can be related to thrusting. Most of them, for instance the folded sequence of the Don Polo Formation above the Los Ratones Thrust (Fig. 2b), can be considered the result of thrustparallel shortening and simple shear during tectonic transport. The fold vergence and the attitude of the axial traces are consistent with this interpretation.
The structure of the Western Precordillera around the boundaries between the Don Polo and Alcaparrosa Formations at the western side of the Tontal Range and in the westernmost area deserves special attention because it provides information about the stratigraphic order of these formations and on the structural evolution of the Western Precordillera. The stratigraphic order of these formations is a classical problem regarding the Early Palaeozoic stratigraphy in the Western Precordillera due to the poorly constrained age of the Don Polo Formation. The Don Polo Formation has been interpreted as older than the Alcaparrosa Formation (Bordonaro, 1999; Von Gosen, 1992) or as a lateral facies change of the later (Keller, 1999). Although the boundaries between both formations along the Rio San Juan section are faults the kinematic analysis carried out during this study indicates that the fault blocks containing the Alcaparrosa Formation always descend with respect to the other fault block (Fig. 2b), supporting an initial upper position for the Alcaparrosa Formation in relation to the Don Polo Formation. Fig. 3 shows a close up view of the structural relationship between these formations at the western side of the Tontal Range where a trachytic dike that can be followed for more than $1 \mathrm{~km}$ intruded along the contact. Other minor parallel dikes can also be seen around the contact. Kinematic criteria such as $C^{\prime}$-type shear surfaces, striations and drag folds record a relative descent of the Alcaparrosa Formation with respect to the Don Polo Formation supporting the interpretation that Don Polo is older than the Alcaparrosa Formation. The intrusion of the basic rocks along the fault contact can be related to the crustal extension that produced the passive continental margin. In this way, the boundary between both formations in Fig. 3 can be interpreted as an initial extensional fault subsequently tilted during thrust emplacement, giving the current appearance of a reverse fault along most of its trace. The folding of this fault to the north of the
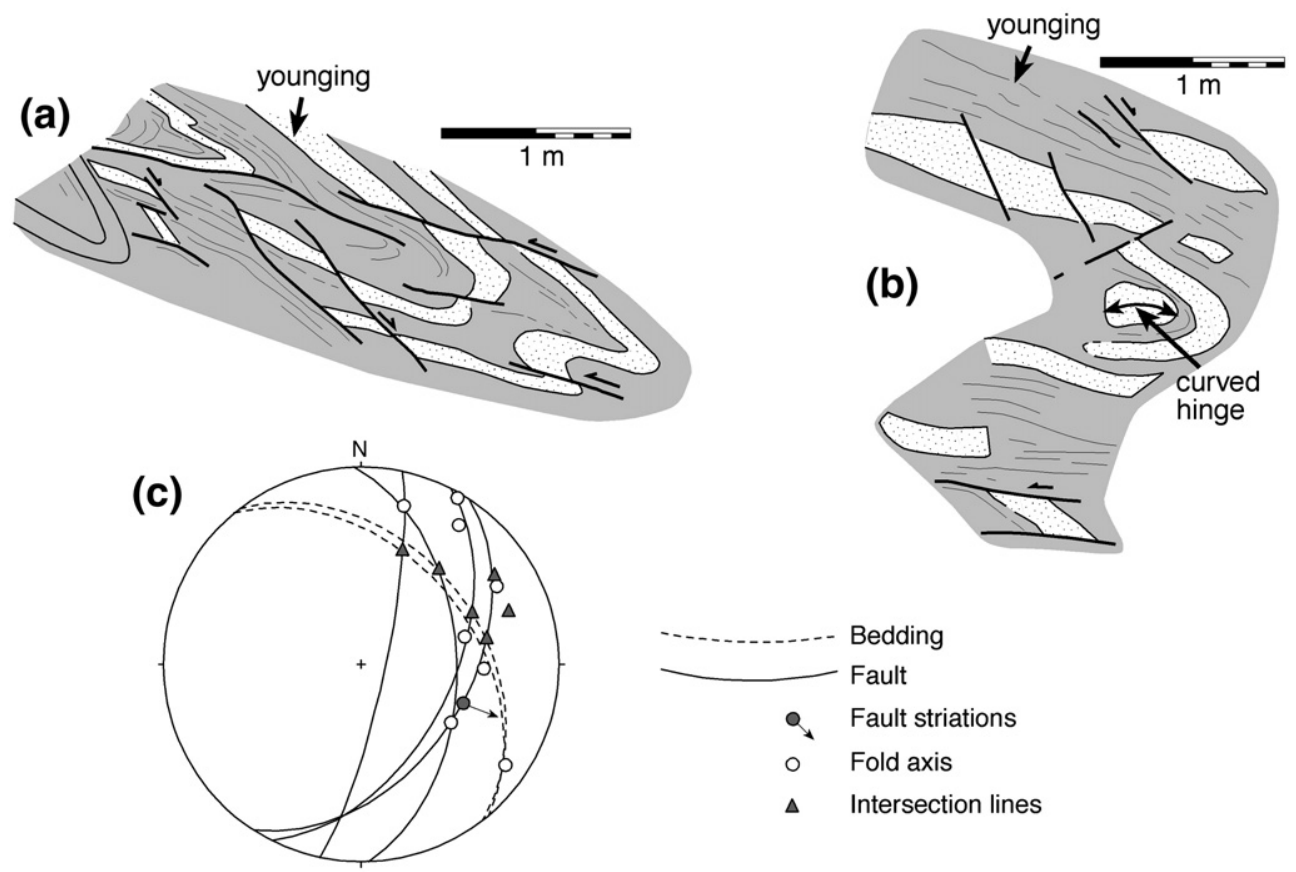

Fig. 7. (a and b) Slump folds in a greywacke-shale sequence of the Alcaparrosa Formation. (c) Stereoplots of structural elements of panels a and b. Location in Fig. 2a. 


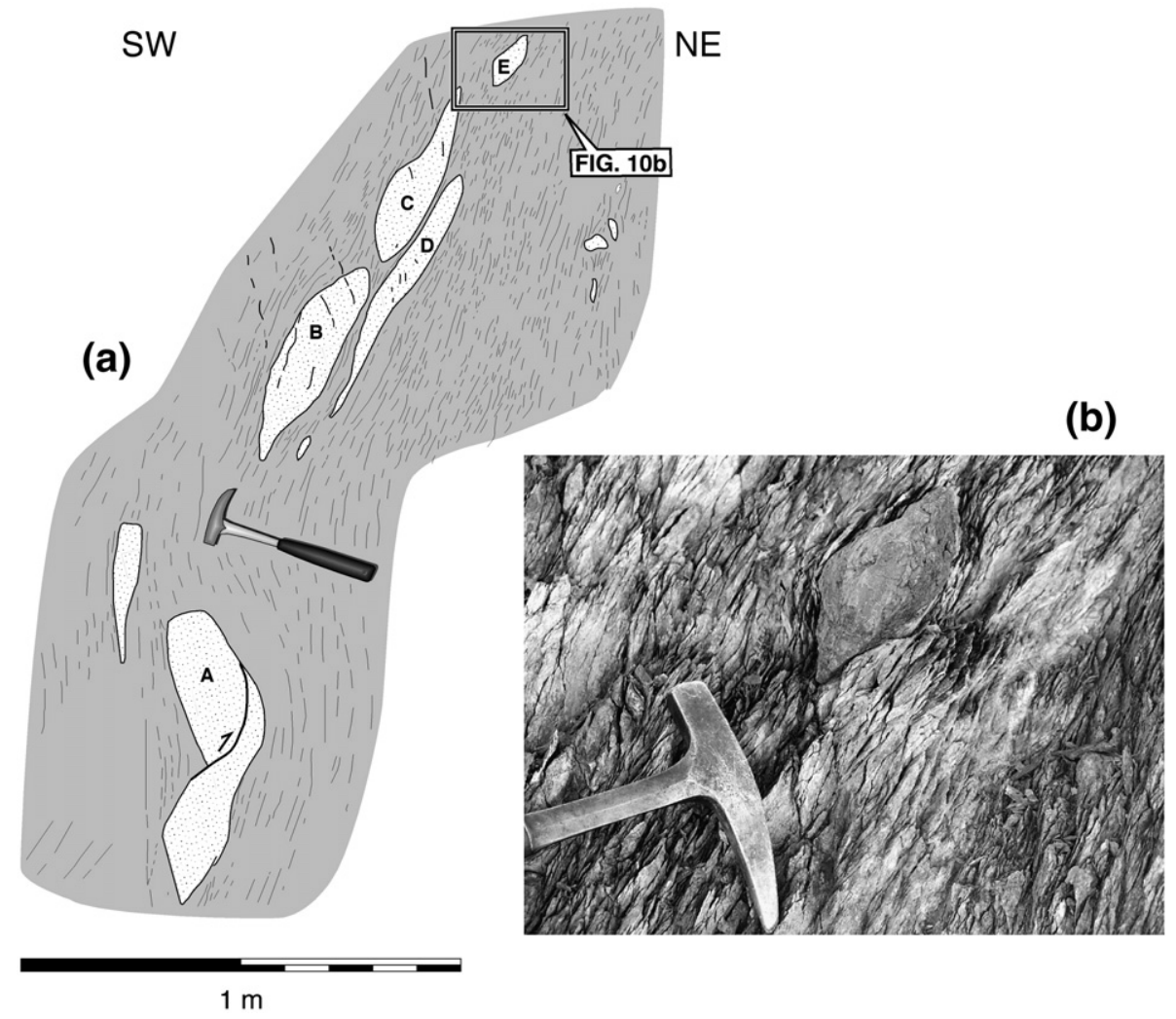

Fig. 8. (a) Pinch-and-swell structures in a greywacke-shale sequence of the Los Sombreros Formation. Location in Fig. 2a. (b) Photo showing the three-dimensional shape of a pinch-and-swell type boudin. Location in panel a.

locality of Fig. 3 (Fig. 2) is another argument to regard it as an early phase fault.

The other contacts between the Don Polo and Alcaparrosa Formations around the San Juan River are thrust surfaces (Fig. 2) and the Alcaparrosa Formation is always in the footwall. The westernmost thrust is west-verging and was breached and folded as a result of the development of the east-verging low-angle thrust known as Alto de Los Pajaritos Thrust, showing that initial

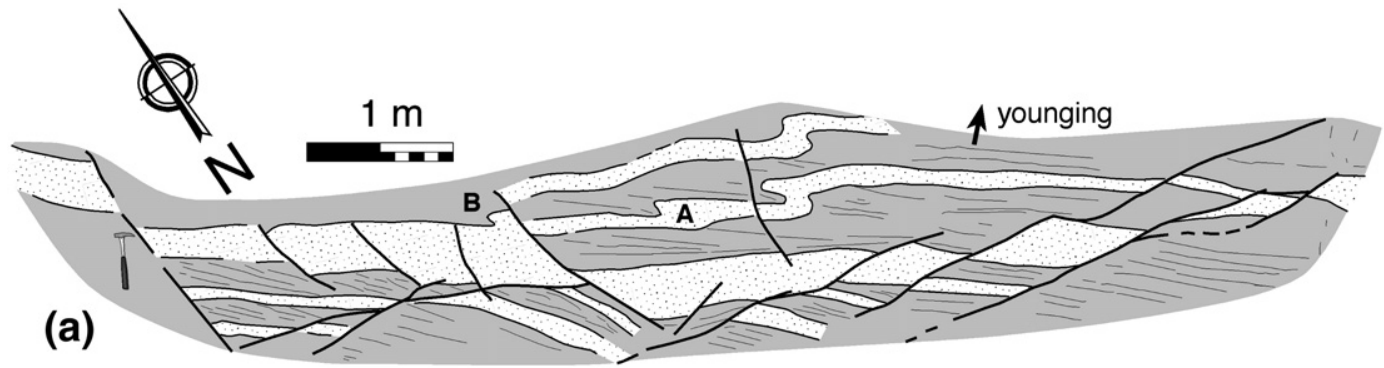

(b)
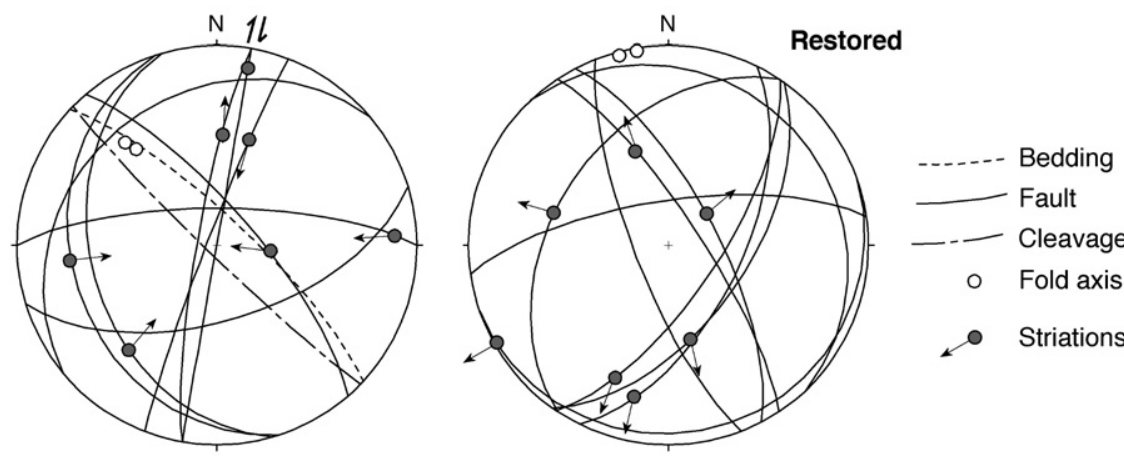

Fig. 9. (a) Slump folds and extensional faults in a greywacke-shale sequence of the Alcaparrosa Formation. (b) Stereoplots of structural elements of panel a. Location in Fig. 2a. 
west-verging thrusts were breached by low angle thrusts with east vergence (Fig. 2b). In this western sector, both formations always display opposite stratigraphic younging in the hanging wall and footwall of the west-verging thrusts, perhaps because these thrusts placed a hanging wall flat on the overturned limb of a footwall syncline (Fig. 2b).

Regarding the structure of the westernmost tectonic unit of the Central Precordillera, two east-verging imbricate thrusts and related folds can be observed in the San Juan Formation. This unit overrides the Tertiary sequence of Pachaco, which covers previous folds (Alonso et al., 2005).

\section{Internal structure of the Ordovician formations at the continent-ocean transition}

The easternmost Ordovician formations (Alcaparrosa and Los Sombreros Formations) in the Western Precordillera display ubiquitous extensional faults with variable extension values, giving rise to boudinaged sequences in some places. Figs. 4a and 5a show two examples of stretched greywacke-shale sequences with intermediate and high layer-parallel extension values respectively. Fig. 4 shows the role played by the mesoscale extensional faults in the disruption of sandstone beds. Both conjugate shear faults and extension fractures developed. Listric faults and footwall and hanging wall flats can also be seen. The extensional shear faults in Fig. 4 have now the appearance of reverse faults, but the microfaults (Fig. 4b) are of hydroplastic type (Petit and Laville, 1987). Hydroplastic faults are closely spaced microfaults, evident in the top or bottom of beds but the displacement decreases rapidly towards the inner part of the bed. This indicates that the fracture propagated in a ductile material. This implies that deformation occurred when those sandstones were still not well lithified and therefore probably with a subhorizontal attitude. The reverse faults in Fig. 4a become normal faults after restoration of the bedding to the horizontal attitude. Fig. $4 \mathrm{c}$ displays the orientation of
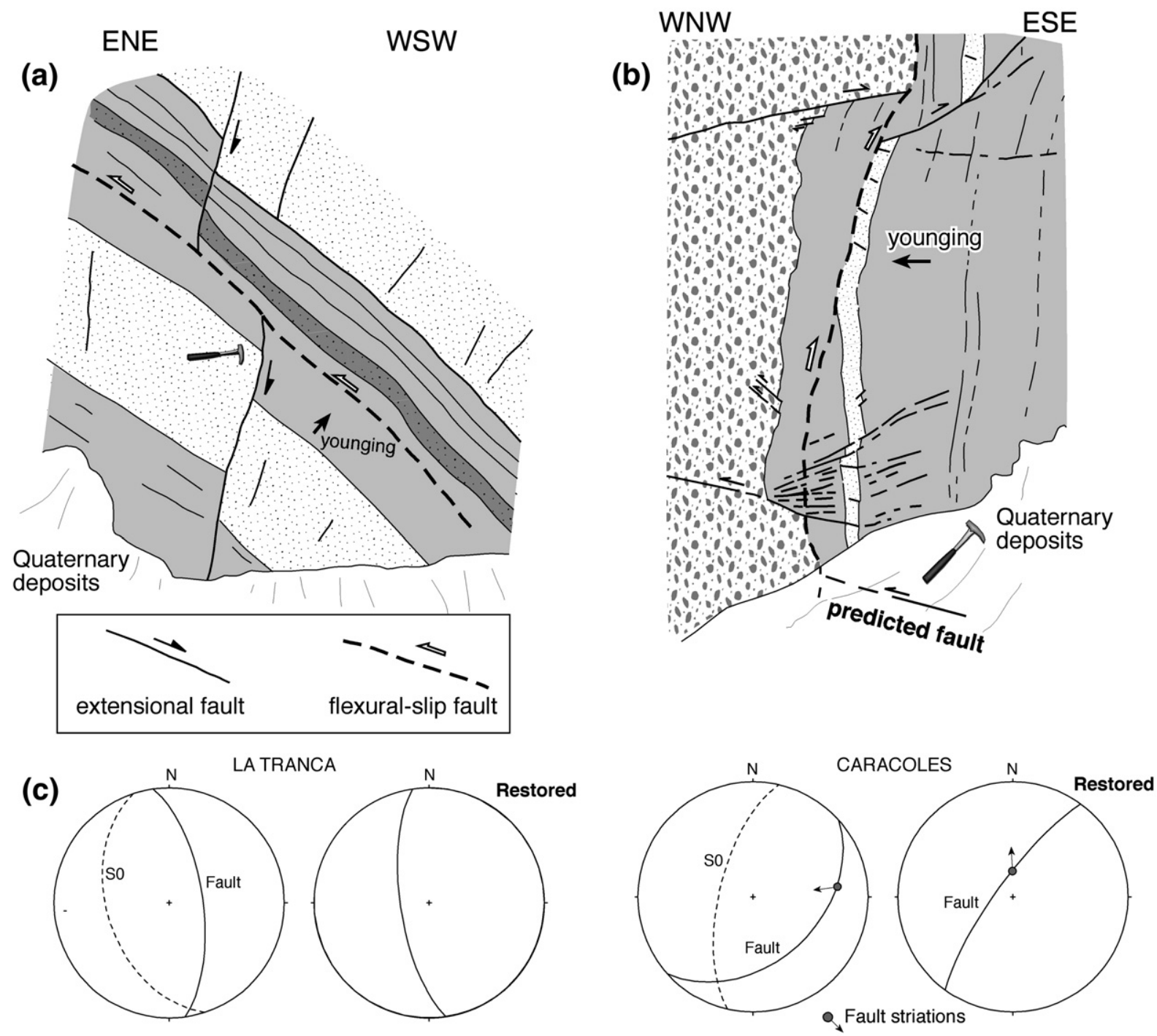

Fig. 10. (a) Extensional fault breached by a flexural-slip fault. (b) Conjugate extensional faults breached by a flexural-slip fault. (c) Stereoplots of structural elements of panels a and b. Location in Fig. 1. 
extensional faults, bedding and other structural elements of Fig. 4a, showing that extension took place in several directions in a non-plane strain deformation regime.

Fig. 5a shows greywacke blocks included in a shale matrix. The individual blocks are bounded by faults displaying striations (Fig. 5b), which are plotted in Fig. 5c. Most of the blocks are rhomboidal in shape (photos 5a), but there are also triangular and trapezoid blocks, depending on whether the blocks are bounded by parallel or oblique shear faults, respectively. Thus, the blocks can be interpreted as the result of layer-parallel extension produced by shear faults and the blocks regarded as boudins. The extension in several directions is also recorded by the threedimensional geometry of the blocks: instead of the unique lineation of common boudins, these display rhombohedral shapes with edges oriented in different directions (Fig. 5b) giving rise to a chocolate tablet structure in plan view. Similar three-dimensional block shapes have been described in block-inmatrix units and interpreted as broken formations during slumping by Steen and Andresen (1997) and Alonso et al. (2006). A weak cleavage developed in the shale matrix, which resembles what some authors have called scaly cleavage in other block-in-matrix formations (Pini, 1999; Vannucchi et al., 2003). $\mathrm{C}$ and $\mathrm{C}^{\prime}$ shear surfaces can also be found, recording a simple shear component during deformation (Fig. 5a). The fact that some of the adjacent boudins in Fig. 5 would not fit well if they were relocated together may be attributed to extension in different directions (Fig. 5c) and to block rotation due to a simple shear component during deformation. The block-in-matrix level of Fig. 5a has been included in the Los Sombreros Mélange by previous authors (Benedetto and Vaccari, 1992; Keller, 1999) that have interpreted this unit as an olistostrome. That level is intercalated with conglomerate and limestone sedimentary breccias. Although we agree in interpreting this mélange as result of slumping, the disintegration of beds in some levels of the Los Sombreros mélange can be explained in terms of extensional deformation with very high extension values during submarine sliding instead of a depositional process such as debris flows, which would have produced a complete distortion of the initial structure of the material. We use the term slumping as the sliding-down of a mass of not wholly consolidated sediment on an underwater slope (AGI Glossary of Geology).

The Ordovician formations located at the continent-ocean transition in the Western Precordillera also contain up to hectometric size limestone blocks of Middle Cambrian and Early Ordovician ages, and their shapes do not differ from those of the greywacke blocks described above. They are also bounded and cut by parallel or conjugate extensional shear faults and surrounded by cleaved shales (Fig. 6). Tension fractures perpendicular to bedding can also be found. In some places, the limestone blocks are lined up (Fig. 6c) evidencing that the blocks are boudins that resulted from stretching of a limestone unit.

We have found evidence of slump folds in the study area. For instance the longest blocks in Fig. 5a seem to be folded, which could be the result of development of slump folds prior to the extensional deformation. Well-developed slump folds can be seen in Fig. 7a and b. A dome-like shape resulting from a curved hinge is shown in Fig. $7 \mathrm{~b}$ and the variable hinge-line orientations (Fig. 7c) are usually interpreted as a result of simple shear with high deformation values (Skjernaa, 1980). In a non-metamorphic setting such as the study area, the high ductility responsible for the high deformation may be attributed to soft-sediment deformation. The slump syncline folds in Fig. 7 were tilted in the western limb of a major syncline illustrated in Fig. 2. After restoration, these folds are consistent with a westward downslope slumping in the Western Precordillera. A ductile behavior
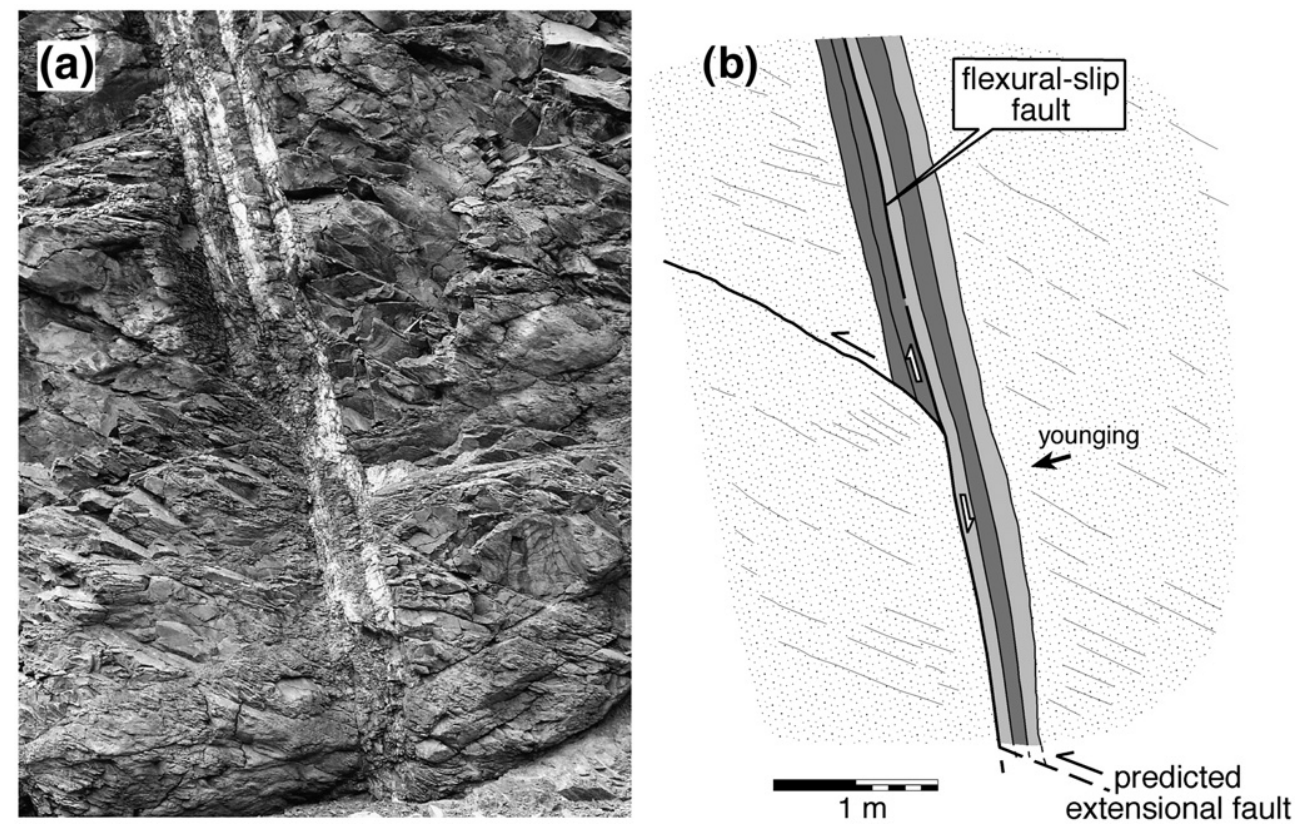

Fig. 11. Photo (a) and sketch (b) of an extensional fault breached by a flexural-slip fault. Notice the geometry similar to a synsedimentary fault, although the explanation is different (see Fig. 12). Location in Fig. 2a. 
during extension is also recorded by the development of some pinch-and-swell structures (Fig. 8). In this figure, the track of both a thick (boudins A, B and C) and a thin bed (boudins D and E) can be recognized. In this case, extension in several directions is recorded by the oblate ellipsoid shape of boudin E (Fig. 8). Although no faults can be seen at boudin boundaries, these display cracked surfaces with hydroplastic microfractures (Fig. 8b). The different length of the boudins and the gaps in between may be attributed to the sequential development of the boudins during the extensional process (Ferguson, 1981).

Moving westwards from the continental margin towards the ocean, extensional structures are scarcer in the Ordovician formations and the proportion of basic rocks in the Alcaparrosa Formation increases. Fig. 9 shows extensional structures developed in this westernmost area, located to the west of the Quebrada de los Ratones and del Salto respectively. In Fig. 9, slump folds and extensional faults developed subsequently. The shape of fold A, or the small size of fold B at the top of a now thick competent bed evidence a high ductility during folding, showing that the sediments were not lithified yet. Both contraction and extension are probably subsequent stages, more or less contemporaneous, during gravitational sliding.

Well-consolidated rocks, located at the lower part of the stratigraphic sequence, also display scarce extensional faults (Figs. 10 and 11). These extensional faults were breached by bedding faults, whose displacement sense is consistent with a flexural-slip mechanism because they display a reverse movement in normal limbs (Fig. 10a) and a normal one in overturned limbs (Fig. 11). Therefore, the normal faults breached by flexural-slip faults predate folding (Fig. 12) and, as a con-
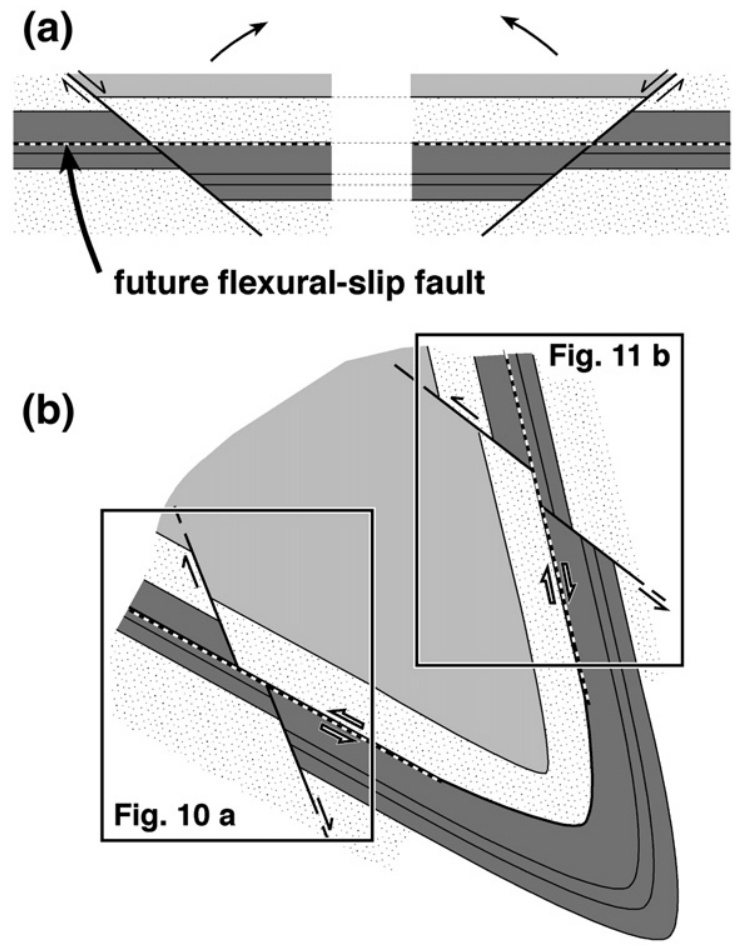

Fig. 12. Explanation of the fault relationships showed in Figs. 10 and 11. Initial normal faults rotate passively in fold limbs and are breached by flexural-slip faults. sequence of their passive rotation in fold limbs, these initial normal faults may appear now as reverse faults, particularly in steep and overturned limbs (Figs. 10 and 11). The breaching of extensional faults by flexural-slip faults produces typical bed thickness changes across the extensional faults, giving rise to apparent synsedimentary faults (Fig. 11). These normal faults can be attributed to the crustal extension that generated the passive continental margin or may represent deep parts of faults related to gravitational collapse.

\section{Discussion and conclusions}

This study documents ubiquitous extensional structures, including normal fault systems and boudinaged sequences developed in a passive margin of Ordovician age in the Western Argentine Precordillera. This passive margin is situated between a carbonate platform of Cambrian-Ordovician age to the east and ocean floor deposits of Ordovician age to the west (Ortiz and Zambrano, 1981; Cuerda et al., 1985; Cingolani et al., 1989; Spalletti et al., 1989; González Bonorino and González Bonorino, 1991; Astini et al., 1996; Bordonaro, 1999). These observations agree with previous interpretation of Dalla Salda et al. (1992), Dalziel et al. (1994) and Keller (1999) who supported an extensional regime for the western Precordillera.

Several observations suggest that most of the extensional structures were caused by gravitational collapse related to submarine sliding: (1) a flattening-type strain with layer-parallel extension in several directions, which is consistent with a laterally unconfined slid mass; (2) the structural association of slump folds and extensional faults; (3) the occurrence of different types of structures that record soft-sedimentary deformation, such as slump folds, microfaults of hydroplastic type and pinch-and-swell structures, could favor the gravitational collapse; and (4) in some places, the sequences dismembered by extensional structures are intercalated with conglomerate layers. We interpret these sequences as submarine slides intercalated with normal sediments. During sliding, limestone and poorly lithified sandstone beds were disrupted by extensional faults, while intercalated clays underwent continuous deformation. The result was the fragmentation of competent beds and a weak cleavage in the shales that usually parallels bedding, evidencing a layer-perpendicular shortening direction. Thus, the internal structure of the slides mainly depends on the degree of sediment lithification during slumping. This internal structure does not differ from other block-in-matrix formations called mélanges, which are located in accretionary or orogenic wedges. The origin of these mélanges has been controversial as they have been interpreted either as a result of gravity sliding or as shear zones related to submarine nappes. Similar fabrics to those described here in the passive margin of the Argentine Precordillera have also been interpreted as a result of gravitational collapse in the Apennines (Naylor, 1981), the Franciscan mélanges (Cowan, 1982) and the Variscan mélanges (Alonso et al., 2006).

The lower part of the stratigraphic sequence was well-lithified during deformation but also display scarce extensional faults. These normal faults can be related to $\mathrm{W}-\mathrm{E}$ crustal extension during Ordovician times or may represent deeper parts of the 
submarine landslides. During the subsequent compressional stages, these normal faults were tilted in fold limbs and truncated by flexural-slip faults, evidencing that they predate folding. The breaching of extensional faults by flexural-slip faults produces typical bed thickness changes across the extensional faults, giving rise to apparent synsedimentary faults.

The gravity slumping inferred from structural data and the west-dipping paleoslope indicated by the slump folds are consistent with the palaeogeography inferred from previous sedimentary research, that locates an Ordovician continental slope between the ocean floor of the westernmost part of the Precordillera and the carbonate platform of the Central Precordillera, interpreted as a passive continental margin.

\section{Acknowledgments}

We are grateful to reviewers Drs. L. A. Spalletti and N. H. Woodcock whose comments have improved the original manuscript. This work has been funded by DGICYT (Spanish Ministry of Education and Science) projects BTE02-04316-C0303, CGL2006-12415-C03-02/BTE and the Consolider-Ingenio 2010 Programme, under project CSD2006-0041, "Topo-Iberia”.

\section{References}

Alonso, J.L., Rodríguez Fernández, L.R., García-Sansegundo, J., Heredia, N., Farias, P., Gallastegui, J., 2005. Gondwanic and Andean structure in the Argentine Central Precordillera: the Río San Juan section revisited. 6th International Symposium on Andean Geodynamics. Extended Abstracts IRD Editions (Institut de Recherche pour le Développement), París. ISBN: 2-7099-1575-8, pp. 36-39.

Alonso, J.L., Marcos, A., Suárez, A., 2006. Structure and organization of the Porma mélange: progressive denudation of a submarine nappe toe by gravitational collapse. American Journal of Science 306, 32-65.

Amenabar, C.R., Di Pasquo, M., 2006. Nuevos datos paleontológicos de la Formación El Ratón, provincia de San Juan, Carbonífero Inferior de Argentina. XIII Simposio Argentino de Paleobotánica y Palinología, Bahía Blanca (Argentina) 123.

Amos, A.J., 1981. Correlación de las formaciones marinas carbónicas y pérmicas de Argentina. Anais da Academia Brasileira de Ciençias (Río de Janeiro) 53, 347-356.

Amos, A.J., Quartino, B.J., Zardini, R.A., 1971. Geología de la región de Barreal-Calingasta, estratigrafía y estructura. In: Quartino, B.J., Zardini, R.A., Amos, A.J. (Eds.), Estudio y Exploración de la Región de BarrealCalingasta. Provincia de San Juan, Argentina, (Monografia de la Asociación Geológica Argentina), 1, pp. 15-67.

Aparicio, V., Cuerda, A.J., 1976. Nuevos hallazgos de graptolites en la vertiente occidental de la Precordillera de San Juan, Calingasta. Ameghiniana 13, 159-168.

Astini, R.A., 1988. Yerba Loca Formation, an Ordovícian Clastic Wedge in Western Argentina: 5th International Symposium Ordovician System, Newfoundland, Canada, Abstracts, 3.

Astini, R.A., 1997. Las unidades calcáreas del Ordovícico Medio y Superior de la Precordillera Argentina como indicadores de una etapa extensional. Actas II Jornadas de Geología de Precordillera, San Juan. Argentina 8-14.

Astini, R.A., 2003. The Ordovician Proto-Andean Basins. In: Benedetto, J.L. (Ed.), Ordovician Fossils of Argentina, Secretaría de Ciencia y Tecnología, Universidad Nacional de Córdoba, pp. 1-74.

Astini, R., Ramos, V.A., Benedetto, J.L., Vaccari, N.E., 1996. La Precordillera: un terreno exótico a Gondwana. XIII ${ }^{\circ}$ Congreso Geológico Argentino y $\mathrm{III}^{\circ}$ Congreso Exploración de Hidrocarburos, (Buenos Aires) Actas V 293-324.

Azcuy, C.L., Cesari, S.N., Longobucco, M.I., 1981. Las plantas fósiles de la Formación El Ratón (Provincia de San Juan). Ameghiniana 18, 11-28.
Baldis, B.A.J., Beresi, M.S., Bordonaro, O., Vaca, A., 1982. Síntesis evolutiva de la Precordillera Argentina. V Congreso Latinoamericano de Geología (Buenos Aires, Argentina) 4, 399-445.

Benedetto, J.L., 2004. The allochthony of the Argentine Precordillera ten years later (1993-2003): A new paleobiogeographic test of the microcontinental model. Gondwana Research 7, 1027-1039.

Benedetto, J.L., Vaccari, N.E., 1992. Significado estratigráfico y tectónico de los complejos de bloques cambro-ordovícicos resedimentados de la Precordillera Occidental, Argentina. Estudios Geológicos 48, 305-313.

Blasco, G., Ramos, V.A., 1977. Graptolitos caradocianos de la Formación Yerba Loca y del cerro La Chilca, Departamento Jáchal, provincia de San Juan. Ameghiniana 13, 312-329. Buenos Aires.

Bordonaro, O., 1980. El Cámbrico en la Quebrada de Zonda, San Juan. Rev. Asociación Geológica Argentina 35, 26-40.

Bordonaro, O., 1999. Cámbrico y Ordovícico de la Precordillera y Bloque de San Rafael. In: Caminos, R. (Ed.), Geología Argentina: Subsecretaría de Minería de la Nación, Instituto de Geología y Recursos Minerales. Anales, vol. 29, pp. 189-204.

Borrello, A.V., 1969a. Embriotectónica y tectónica tensional. Su importancia en la evolución estructural de la Precordillera. Asociación Geológica Argentina 24, 5-13. Buenos Aires.

Borrello, A.V., 1969b. Los geosinclinales de la Argentina. Dirección Nacional de Geología y Minería, Anales 14, 1-188. Buenos Aires.

Bracaccini, O., 1946. Contribución al conocimiento geológico de la Precordillera Sanjuanina-Mendocina. Boletín de Informaciones Petroleras, Buenos Aires 258, 16-17. Buenos Aires.

Bracaccini, O., 1949. El perfil de Tambolar (provincia de San Juan). Revista de la Asociación Geológica Argentina 4, 165-179. Buenos Aires.

Brussa, E.D., Mitchell, C.E., Astini, R.A., 1999. Ashgillian (Hirnantian) graptolites from the western boundary of the Argentine Precordillera. In: Craft, P., Fatka, O. (Eds.), Quo Vadis Ordovician? Acta Universitatis Carolinae. Geologica, vol. 43, pp. 199-202.

Cingolani, C., Cuerda, A., Varela, R., Schauer, O., 1989. Geología de la Precordillera Occidental en la comarca de la Sierra del Tontal, provincia de San Juan, República Argentina. Revista de Comunicaciones del Departamento de Geología, Universidad de Chile (Santiago) 40, 39-56.

Cowan, D.S., 1982. Deformation of partly dewatered and consolidated Franciscan sediments near Piedras Blancas Point, California. In: Leggett, J.K. (Ed.), Trench-Forearc Geology: Geological Society of London Special Publication, vol. 10, pp. 439-457.

Cuerda, A., Cingolani, C., Schauer, O., Varela, R., 1985. El Ordovicico de la Sierra del Tontal, Precordillera de San Juan, República Argentina. Actas del IV Congreso Geológico Chileno (Antofagasta) 1109-1132.

Dalla Salda, L., Cingolani, C., Varela, R., 1992. Early Paleozoic orogenic belt of the Andes in southwestern South America: Result of Laurentia-Gondwana collision? Geology 20, 617-620.

Dalziel, I.W.D., Dalla Salda, L.H., Gahagan, L.M., 1994. Paleozoic Laurentia-Gondwana interaction and the origin of the AppalachianAndean mountain system. Geological Society of America Bulletin 106, $243-252$.

Ferguson, C.C., 1981. A strain reversal method for estimating extension from fragmented rigid inclusions. Tectonophysics 79, T43-T52.

González Bonorino, G., González Bonorino, F., 1991. Precordillera de Cuyo y Cordillera Frontal en el Paleozoico temprano: terrenos bajo sospecha de ser autóctonos. Revista Geológica de Chile 18, 97-107.

Haller, M.A., Ramos, V.A., 1984. Las ofiolitas famatinianas de las Provincias de San Juan y Mendoza. Actas del IX Congreso Geológico Argentino (San Carlos de Bariloche) 2, 66-83.

Heim, A., 1952. Estudios tectónicos en la Precordillera de San Juan, en los ríos San Juan, Jáchal y Huaco. Revista de la Asociación Geológica Argentina 7, $11-70$.

Kay, S.M., Ramos, V.A., Kay, R., 1984. Elementos mayoritarios y trazas de las vulcanitas ordovícicas en la Precordillera Occidental: basaltos de rift oceánicos tempranos próximos al margen continental. Actas del $9^{\circ}$ Congreso Geológico Argentino 2, 48-65.

Keller, M., 1999. Argentine Precordillera: sedimentary and plate tectonic history of a Laurentian crustal fragment in South America. The Geological Society of America, Special Paper 341, 1-131. 
Kerllenevich, S.C., Cuerda, A., 1986. Monograptus priodon (Bronn) (Graptolithina) en la Formación La Chilca; Precordillera de San Juan, Argentina Ameghiniana 23, 119-126.

Manceñido, M.O., Sabatini, N., 1974. La Fauna de la Formación Del Salto (Paleozoico Superior de la provincia de San Juan), Parte 2, Gastrópoda. Ameghiniana 10, 326-338.

Manceñido, M.O., González, C.R., Damborenea, S.E., 1976a. La Fauna de la Formación Del Salto (Paleozoico Superior de la provincia de San Juan), Parte 3, Bivalvia 1. Ameghiniana 13, 65-106.

Manceñido, M.O., González, C.R., Damborenea, S.E., 1976b. La Fauna de la Formación Del Salto (Paleozoico Superior de la provincia de San Juan), Parte 4, Bivalvia 2. Ameghiniana 13, 85-107.

Naylor, M.A., 1981. Debris flow (olistostromes) and slumping on a distal passive continental margin: the Palombini limestone-shale sequence of the northern Apennines. Sedimentology 28, 837-852.

Nullo, F.E., Stephens, G.C., 1996. El alóctono Calingasta en la Precordillera Occidental; una relación entre Sudamérica y Norteamérica. Actas del $13^{\circ}$ Congreso Geológico Argentino y $3^{\circ}$. Congreso de Exploración de Hidrocarburos 5, 325-330. Buenos Aires.

Ortiz, A., Zambrano, J.J., 1981. La provincia geológica de la Precordillera Oriental. Actas del VIII Congreso Geológico Argentino (San Luis) 3, 59-74

Petit, J.P., Laville, E., 1987. Morphology and microstructures of hydroplastic slickensides in sandstone. In: Jones, M.E., Preston, R.M.F. (Eds.), Deformation of Sediments and Sedimentary Rocks. Geological Society of London (Special Publication), vol. 29, pp. 107-121.

Pini, G.A., 1999. Tectonosomes and olistostromes in the Argille Scagliose of the Northern Apennines, Italy. Geological Society of America Special Paper $335,1-73$

Ramos, V.A., 2004. Cuyania, an exotic block to Gondwana: review of a historical success and the present problems. Gondwana Research 7, 1009-1026.

Ramos, V.A., Jordan, T.E., Allmendinger, R.W., Kay, S.M., Cortés, J.M., Palma, M., 1984. Chilenia: un terreno alóctono en la evolución paleozoica de los
Andes centrales. Actas del IX Congreso Geológico Argentino (San Carlos de Bariloche) 2, 84-106.

Ramos, V.A., Jordan, T.E., Allmendinger, R.W., Mpodozis, C., Kay, S.M., Cortés, J.M., Palma, M., 1986. Paleozoic Terranes of the Central ArgentineChilean Andes. Tectonics 5, 855-880.

Rapalini, A.E., Cingolani, C.A., 2004. First Late Ordovician paleomagnetic pole for the Cuyania (Precordillera) terrane of western Argentina: a microcontinent or a Laurentian Plateau? Gondwana Research 7, 1089-1104.

Schauer, O., Varela, R., Cingolani, C., Cuerda, A., 1987. Presencia de una graptofauna Llandeillana-Caradociana en la Formación Alcaparrosa, del flanco occidental de la Sierra del Tontal (Precordillera de San Juan). Ameghiniana 24, 151-158.

Sessarego, H.L.F., 1988. Estratigrafía de las secuencias epiclásticas devónicas a triásicas aflorantes al norte del río San Juan y al oeste de las Sierras del Tigre, provincia de San Juan. PhD Thesis, Universidad de Buenos Aires, (unpublished).

Skjernaa, L., 1980. Rotation and deformation of randomly oriented planar and linear structures in progressive simple shear. Journal of Structural Geology 2, 101-109.

Spalletti, L.A., Cingolani, CA., Varela, R., Cuerda, A.J., 1989. Sediment gravity flow deposits of an Ordovician deep-sea fan system (western Precordillera, Argentina). Sedimentary Geology 61, 287-301.

Steen, Ø., Andresen, A., 1997. Deformational structures associated with gravitational block gliding: examples from sedimentary olistoliths in the Kalvåg mélange, western Norway. American Journal of Science 297, 56-97.

Turco Greco, E., Zardini, R., 1984. Un equinodermo del Paleozoico inferior en la Precordillera de San Juan, Calingasta. Revista de la Asociación Geológica Argentina 39, 300-303.

Vannucchi, P., Maltman, A., Betelli, G., Clennell, B., 2003. On the nature of scaly fabric and scaly clay. Journal of Structural Geology 25, 673-688.

Von Gosen, W., 1992. Structural evolution of the Argentine Precordillera: the Rio San Juan section. Journal of Structural Geology 14, 643-667. 